and generally bodes ill for prognosis. Richard Young at the Massachusetts Institute of Technology in Cambridge and his colleagues studied the encoded protein, c-Myc, in human tumour cells. The researchers found that c-Myc accumulates at the regulatory sequences of active genes and boosts their transcription into RNA, amplifying the geneexpression program already in place.

Meanwhile, Keji Zhao and David Levens at the National Institutes of Health in Bethesda, Maryland, and their colleagues analysed normal mouse cells. They showed that c-Myc did not induce gene expression itself, but rather amplified the expression of nearly all active genes.

This mechanism could help to explain the diverse effects of $\mathrm{c}-\mathrm{Myc}$ in different cancers. Cell 151, 56-67; 68-79 (2012) ORGANISMAL BIOLOGY

\section{How slime moulds keep track}

Sticky trails of sugar and protein secreted by slime moulds help the single-celled organisms to find their way, by marking where they have previously travelled.

Christopher Reid at the University of Sydney in Australia and his team found that the slime mould Physarum polycephalum (pictured) which senses and migrates towards chemical cues such as glucose - avoids its own secretions if possible, preferring to seek food in unexplored areas. When researchers used a U-shaped barrier to trap the creature en route to a glucose snack, $96 \%$ of organisms found their way out within 120 hours, mostly by trying untested territory. However, when the entire environment was coated in slime, only $33 \%$ of slime moulds reached the goal in that time, and those that did travelled longer distances than organisms in a slime-free setting.

Slime moulds use their trails to navigate complex environments more efficiently, the team concludes.

Proc. Natl Acad. Sci. USA

http://dx.doi.org/10.1073/

pnas.1215037109 (2012)

\section{EARTH SCIENCE}

\section{Planetary wanderlust}

Earth's continents seem to be drifting westward by around 0.2 degrees every million years. This is a sign that the planet is experiencing true polar wander - the rotation of Earth's solid outer layer relative to its spin axis.

To distinguish true polar wander from the overlapping motion of individual tectonic plates, Pavel Doubrovine and his colleagues at the University of Oslo defined a new global reference frame, which they consider to be accurate for the past 120 million years. To do so, the researchers used the computed tracks and present positions of volcanic hot spots in the Pacific Ocean and the Indo-Atlantic hemisphere. The rate of true polar wander has increased systematically over the past 40 million years, the team found.

J. Geophys. Res. http://dx.doi. org/10.1029/2011JB009072 (2012)

\section{FISHERIES \\ Questioning tuna marine reserves}

Closing off areas of the Pacific Ocean to bigeye-tuna fishing might not be the most effective conservation measure, a modelling study suggests.

Pacific populations of bigeye tuna (Thunnus obesus) are being threatened by both 'purse seine' fishing, which involves catching large schools of fish with nets, and longline

COMMUNITY CHOICE

The most viewed papers in science

\title{
STATISTICS
}

\section{In sport, winners do take all}

HIGHLY READ
on www.njp.org
in September

The distribution of scores and prize money in sport is governed by the same power laws that determine the distribution of city size or wealth: a few top-ranked players and teams accumulate the vast majority of the prizes.

Wei Li of Central China Normal University in Wuhan and his colleagues came to this conclusion after studying ranking data from 12 sports, including golf, tennis and snooker. Detailed analysis of the tennis data revealed that when any two players compete, the probability that the higher-ranked player will win is related to the difference in the individuals' rankings. Moreover, the data from all 12 sports seem to follow the Pareto principle, or $80-20$ rule: $20 \%$ of the players accumulate $80 \%$ of the points and money.

N. J. Phys. 14, 093038 (2012)

fishing. This led authorities to close two areas to purse seine fishing in 2009 , but the effects of these closures have never been evaluated. John Sibert at the University of Hawaii in Honolulu and his colleagues used a model of tuna population dynamics to simulate the effects of different fishery-management practices on tuna biomass.

The researchers found that closing high-seas enclaves in the western central Pacific Ocean to purse seine fishing had little effect on the fishes' biomass. Reducing longline fishing in spawning areas, and prohibiting the use of fish-aggregating devices that increase the incidental catch of bigeye tuna, seem to be more efficient ways of maintaining tuna populations.

Proc. Natl Acad. Sci. USA

http://dx.doi.org/10.1073/

pnas.1209468109 (2012)

ANIMAL BEHAVIOUR

\section{Echolocation for communication}

Animals such as bats use echolocation as a form of sonar to find food at night, but they might also use it to communicate.

Mirjam Knörnschild at the

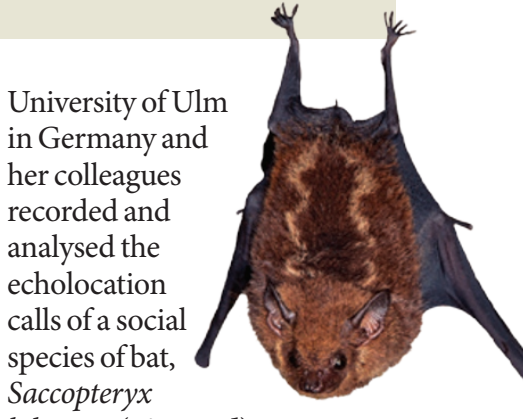

bilineata (pictured), at

three sites in Costa Rica.

The researchers found that

roosting males seem to

detect the echolocation calls

of an approaching bat from at least five metres away. In response to an incoming male, the bats emitted aggressive vocalizations suggestive of territorial defence. If the approaching bat was female, however, the males responded with courtship songs.

The males must be using echolocation, the authors conclude, because in low-light conditions at a distance of at least five metres, neither visual nor odour cues could provide the roosting bats with information about the sex of their visitor.

Proc. $R$. Soc. B http://dx.doi. org/10.1098/rspb.2012.1995 (2012)

\section{$\rightarrow$ NATURE.COM}

For the latest research published by Naturevisit:

www.nature.com/latestresearch 